\title{
I nvasive fungal diseases in children with hematological malignancies and stem cell transplant recipients
}

\author{
José Ramón Molina, R. Rojas, J. Serrano, P. Gómez \\ Hematology Department and Bone Marrow Transplantation Unit, University Hospital "Reina Sofia”, Cordoba, Spain \\ Correspondence: José Ramón Molina. Address: Hematology Department and Bone Marrow Transplantation Unit, \\ University Hospital Reina Sofia, Avda Menendez Pidal s/n, 14004 Cordoba, Spain. E-mail: josehristomoli@yahoo.es
}

Received: July 15, 2012

Accepted: August 27, 2012

Online Published: November 7, 2012

DOI : $10.5430 / \mathrm{jhm} . \mathrm{v} 2 \mathrm{n} 4 \mathrm{pl}$

URL: http://dx.doi.org/10.5430/jhm.v2n4p1

\begin{abstract}
Invasive Fungal Disease (IFD) remains a major cause of morbidity and mortality in patients with hematological malignancies or undergoing stem cell transplantation. New surrogate markers of IFD -galactomannan antigen, $\beta$-D-glucan, fungal polymerase chain reaction...-and the availability of modern antifungal drugs have changed the management of this serious complication, but both have limitations in children. There are still some unclear issues, particularly in pediatric patients, regardless of the medical and economic possibilities of hospitals: IFD remains difficult to diagnose in a timely way, stem cell transplant recipients have different risk of IFD, antifungal drugs are not free from adverse effects and prospective studies in children are scarce. In this sense, diagnosis criteria have to be assessed, risk stratification should be redefined and the different types of prophylaxis/treatment -prophylaxis, preemptive, empiric and targeted treatment- must be used correctly. We consider low risk for IFD children undergoing autologous stem cell transplantation and children with acute lymphoblastic leukemia; both should receive fluconazole as primary prophylaxis and empiric therapy with an agent with activity against mold. In those who undergoing allogeneic stem cell transplantation or chemotherapy for acute myeloid leukemia, prophylaxis should be performed with a mold active agent -triazoles priority-. We rarely use preemptive therapy because of a high false positive rate of galactomannan. In proven and probable IFD we use targeted therapy, selecting a drug based on the type of infection, sensitivity to the drug in our hospital and prior antifungal prophylaxis/treatment. In selected patients, antifungal combination therapy should be a valid option. Despite great advances, there are still thought provoking questions on the diagnosis and management of IFD in children with hematological diseases.
\end{abstract}

\section{Key words}

Invasive fungal disease, Children, Hematological diseases, Stem cell transplantation

\section{I ntroduction}

Invasive Fungal Disease (IFD) remains a crucial problem in patients with hematological pathologies or undergoing stem cell transplantation ${ }^{[1-3]}$. Despite the improvement in critical care and the advent of new antifungal drugs ${ }^{[4,5]}$, the use of more aggressive therapies and prolonged neutropenia heightens the chances of developing fungal infections ${ }^{[6,7]}$. The incidence of IFDs has significantly increased in pediatric cancer patients and has been recently found to be $21 \%$ in acute lymphoblastic leukemia, $15 \%$ in acute myeloid leukemia and $25 \%$ following stem cell transplantation ${ }^{[8]}$. The majority of these IFDs are caused by Aspergillus spp. and Candida spp. ${ }^{[9-13]}$ but recently others IFDs like Zygomycetes, Fusarium 
spp. or Scedosporium spp. appear in an increasing percentage ${ }^{[14]}$, probably due to the use of a mold active agent as antifungal prophylaxis ${ }^{[15,16]}$. The most frequent isolated Aspergillus is A. fumigatus ${ }^{[13,17]}$. Moreover, there are several differences between children and adults in the diagnostic markers and, of course, on the availability, pharmacokinetic, safety and efficacy of antifungal drugs ${ }^{[18]}$. In this review, we discuss the way and difficulties we have in the diagnosis of IFD in children with hematological pathologies and options for the best practices in treating them.

\section{Diagnostic criteria}

An early diagnosis of IFD is one of our main goals when we meet a high-risk pediatric patient, because early and appropriate treatment is critical for survival ${ }^{[19]}$. This diagnosis begins with an assessment of risk that includes several issues like primary hematological disease, depression of the cellular immune status, particularly the intensity and duration of neutropenia, and immunosuppressive therapy ${ }^{[20]}$. Children undergoing allogeneic hematopoietic stem cell transplantation (allo-HSCT), induction and consolidation chemotherapy for acute myeloid leukemia and reinduction chemotherapy for relapsed acute lymphoblastic leukemia are high-risk patients for developing IFD ${ }^{[21]}$. Children with these conditions should be monitored closely with daily physical examinations and scheduled laboratory microbiological tests. We should reserve diagnostic imaging tests for patients with suspected IFD in order to avoid unnecessary exposure to radiation ${ }^{[22]}$. One of the main problems we face in the IFD diagnosis in children is the lack of evidence of laboratory tests like Galactomannan Antigen (GM), 1-3 $\beta$-D glucan and Aspergillus and Fungal Polymerase Chain Reaction (PCR), which have been proven to be successful in adults and less so in children ${ }^{[23]}$. It is often difficult to collect appropriate tissue specimens for culture or histology; fungal cultures lack sensitivity ${ }^{[24,25]}$ and histological diagnosis requires invasive procedures. In the diagnosis of IFD, we use the revised European Organization for Research and Treatment of Cancer/Mycoses Study Group (EORTC/MSG) criteria ${ }^{[25]}$.

\subsection{Galactomannan antigen test}

GM is a measurable biological marker in the extracellular fluid during the growth of Aspergillus hyphae and cell wall turnover. US Food and Drug Administration approved the standardized methods for GM detection based on antigen enzyme immunoassay. After promising results in adults ${ }^{[26]}$, it has shown controversial and disappointing results with low sensitivity in children; high false positive rates due to piperacillin/tazobactam or amoxicillin/clavulanate antibiotic treatment ${ }^{[27,28]}$, cow's milk components ${ }^{[29]}$ and Bifidobacterium spp. ${ }^{[30]}$. Moreover, Marr et al. indicated that antifungal therapy decreases sensitivity of GM in adults ${ }^{[31]}$, leading to false negative results, which is also likely to occur also in children.

Steinbach et al. performed a prospective study in pediatric allo-HSCT recipients. Patients undergoing cord blood allo-HSCT received prophylaxis with voriconazole and the remaining with fluconazole with a $\mathrm{GM}>0.5$ considered positive. GM test showed a per-patient specificity of $87.3 \%$, but it was higher (91.5\%) when excluding samples from patients receiving piperacillin/tazobactam ${ }^{[32]}$. Hayden et al. reported a study in 56 hematology-oncology pediatric patients of whom 17 had proven or probable invasive aspergillosis (IA), sensitivity and specificity were $65.7 \%$ and $87 \%$ respectively, using a GM cut-off of 0.5 . They obtained a positive GM result in most cases before clinical or radiographic evidence of infection ${ }^{[33]}$. Castagnola et al. published their experience in 195 periods at risk in children with cancer or undergoing hematopoietic stem cell transplantation; sensitivity was $32 \%$ while specificity was $98 \%$, with best results in children following chemotherapy compared with those undergoing allo-HSCT. None of the patients received antifungal prophylaxis against Aspergillus and the test result was defined as positive when the GM cut-off was $>0.7$ in a sample or between 0.5 and 0.7 in at least two consecutive samples ${ }^{[34]}$. Based on our experience between 2006 and 2010, in children under 14 years undergoing allo-HSCT using voriconazole as primary antifungal prophylaxis, per-episode specificity was $72.2 \%$ (unpublished data). The test for galactomannan antigen in the serum was performed twice weekly using AGA EIA (Platelia Aspergillus; BioRad Laboratories) ${ }^{[35]}$. Galactomannan test results were interpreted as positive when an optical 
density index of $\geq 0.5$ was reached in two consecutive measurements or $\geq 0.8$ in one sample ${ }^{[36]}$ and, nowadays, we do not usually use piperacillin/tazobactam.

\subsection{1-3 $\beta$-d-Glucan}

1, 3- $\beta$-d-Glucan ( $\beta$-glucan) is a cell wall component found in several fungal pathogens, including Candida spp. and Aspergillus spp., and can be detected through two commercial kits: Fungitec G-test and Fungitell. Smith et al. found higher $\beta$-glucan levels in non-hematological children, but with several false-positive results ${ }^{[37]}$. In a recent study in 63 children with acute leukemia, Mokaddas et al. warn of rising levels of $\beta$-glucan in children colonized by Candida without current infection ${ }^{[38]}$. Although discouraging information is available, new prospective studies are needed in pediatric patients with hematological diseases to validate this test. Until recently, this technique was not routinely used in our hospital.

\subsection{Fungal DNA PCR}

In the last years, detection of Aspergillus nucleic acid by PCR in bronchoalveolar lavage fluid and serum is another useful tool for the diagnosis of IA. Hummel et al. studied Aspergillus PCR in 71 onco-hematological pediatric patients with suspected IFD, sensibility and specificity were $80 \%$ and $81 \%$ respectively ${ }^{[39]}$, while Armenian et al. performed a weekly Aspergillus PCR in children with acute leukemia $(\mathrm{n}=58)$ or undergoing allo-HSCT $(\mathrm{n}=20)$ finding only 2 positive Aspergillus PCR in 23 patients with IFD (3 probable and 20 possible). He found a high rate of false positives ${ }^{[40]}$. El-Mahallawy et al. designed a study in high-risk pediatric cancer patients; they used GM and pan-fungal PCR to investigate the diagnostic utility of these markers. Pan-fungal PCR showed sensitivity of $75 \%$ and specificity of $92 \%$, while negative PCR in the proven and probable cases was closely related to previous antifungal therapy ${ }^{[41]}$. Landlinger et al. established a two-reaction real-time PCR assay with highly sensitivity detection of more than 80 fungal pathogens in 125 high-risk children; they presented a sensitivity and specificity of the assay of $96 \%$ and $77 \%$ respectively, but with a positive predictive value of $62 \%{ }^{[42]}$. Although PCR for Aspergillus may be a useful marker in pediatric patients, especially those on diets rich in dairy products or receiving piperacillin/tazobactam, in our experience the use of Aspergillus PCR has not achieved satisfactory results due to its low specificity. However, it is a technique that should be validated in further prospective studies.

Figure 1. Chest radiography and CT scan of a girl with invasive aspergillosis

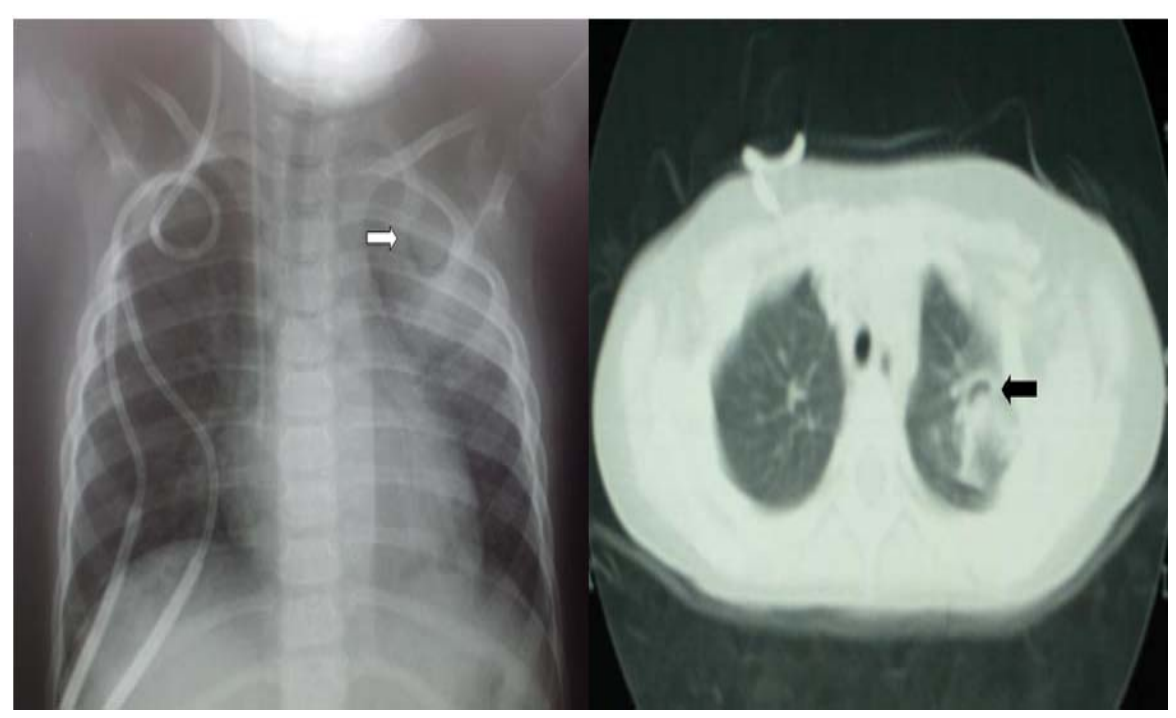




\subsection{I maging test}

Although chest radiograph usually do not report diagnostic findings, in some patients this test may show interesting images, as in Figure 1. In this way sinus, chest or abdominal Computed Tomography scan is the election test in the early detection of IFD. However, these imaging studies also lack specificity related to fungal species. In a multicenter retrospective analysis of 139 pediatric patients with IA, Burgos et al. showed that the most frequent radiological finding was nodules in $59 \%$ of children followed by cavitation, halo sign and air-crescent sign in $24.5 \%, 10.9 \%$ and $2.2 \%$ of children, respectively ${ }^{[13]}$. Abdominal ultrasound is the imaging modality of choice for children with suspected hepatosplenic candidiasis ${ }^{[43]}$ (Figure 2), although nuclear magnetic resonance can prove lesions not detected by ultrasound [44].

Figure 2. Hepatosplenic candidiasis lesions detected by abdominal ultrasound in a girl undergoing allogeneic stem cell transplantation.

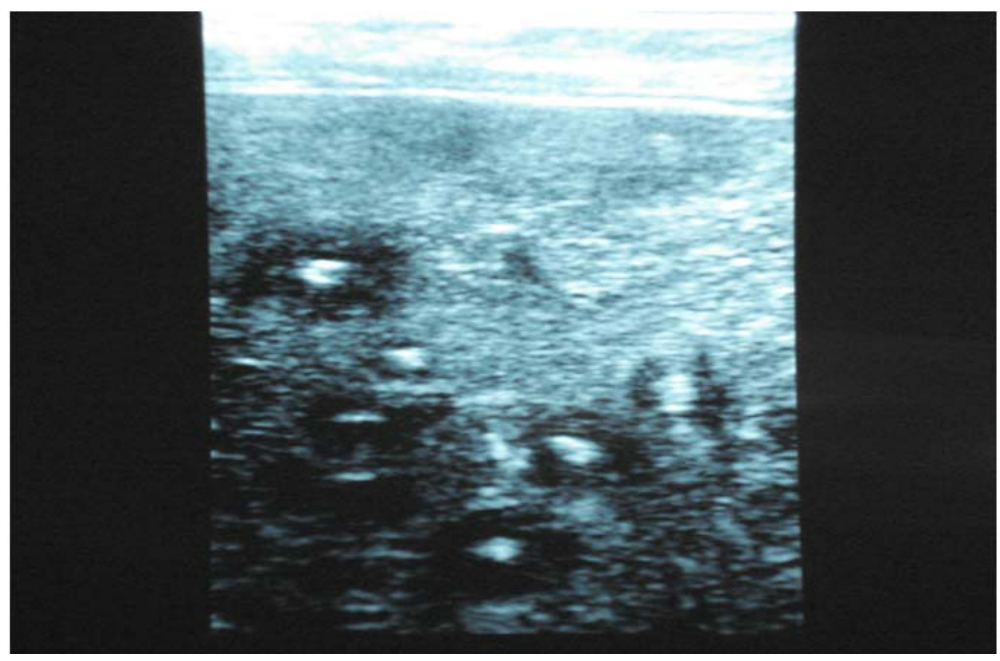

\section{Most commonly used antifungal drugs in children}

Despite important achievements and new information available, the use of antifungal agents in pediatric patients is still partially limited by the fact that not all of them are now approved in this population, the appropriate dosage of these drugs has not been definitely established for all age groups due to variable pharmacokinetic and pharmacodynamic properties and data providing information on safety and efficacy of different agents is still insufficient. In Table 1 and in the following lines, we will briefly review the main antifungal drugs used in pediatric patients.

\subsection{Azoles}

Fluconazole is approved mainly for treating invasive candidiasis and as prophylaxis of IFD in immunocompromised children due to chemotherapy and/or radiotherapy. Voriconazole is approved for treatment of IA, fusariosis and scedosporiosis, and for primary treatment of invasive candidiasis in non-neutropenic patients. There is no data available in children under 2 years old. With regard to posaconazole, the safety and efficacy in children under 18 years of age has not yet been established, but different studies have reported promising results in pediatric patients ${ }^{[45,46]}$. Itraconazole is not approved for use in children unless the potential benefits outweigh the risks; anyway some groups have used it with acceptable results ${ }^{[47]}$. However, severe neurotoxicity has been associated with concomitant use of vincristine ${ }^{[48]}$.

Evidence on the best approach to azole therapeutic drug monitoring is still limited. One of the challenges is to define the optimal threshold levels, especially for voriconazole and posaconazole. It has been suggested a minimum concentration target for voriconazole of $>1.7 \mathrm{mg} / \mathrm{L}$, particularly in children and when treating pathogens with higher minimum inhibitory 
concentrations (MIC) for voriconazole (e.g., Scedosporium spp.) ${ }^{[49]}$. However, the therapeutic value of serum level monitoring of posaconazole remains uncertain and based on available evidence, posaconazole cannot be recommended for routine clinical use at this time.

Table 1. Main antifungal drugs used in hematological adult and pediatric patients

\begin{tabular}{|c|c|c|c|c|}
\hline Antifungal Drug & Formulation & Pediatric dose & Adult dose & $\begin{array}{l}\text { Indications in hematological } \\
\text { children }\end{array}$ \\
\hline AmB-D & i.v. & $0.3-1.5 \mathrm{mg} / \mathrm{kg} / 24 \mathrm{~h}$ & $0.3-1.5 \mathrm{mg} / \mathrm{kg} / 24 \mathrm{~h}$ & Severe systemic fungal infections. \\
\hline AmB-LC & i.v. & $5 \mathrm{mg} / \mathrm{kg} / 24 \mathrm{~h}$ & $5 \mathrm{mg} / \mathrm{kg} / 24 \mathrm{~h}$ & Severe systemic fungal infections. \\
\hline L-AmB & i.v. & $3 \mathrm{mg} / \mathrm{kg} / 24 \mathrm{~h}$ & $3 \mathrm{mg} / \mathrm{kg} / 24 \mathrm{~h}$ & $\begin{array}{l}\text { Severe systemic fungal infections. } \\
\text { Empirical treatment. }\end{array}$ \\
\hline Caspofungin & i.v. & $50 \mathrm{mg} / \mathrm{m}^{2} / 24 \mathrm{~h}$ & $50 \mathrm{mg} / \mathrm{m}^{2} / 24 \mathrm{~h}$ & $\begin{array}{l}\text { Invasive candidiasis. } \\
\text { Empirical treatment. }\end{array}$ \\
\hline Micafungin & i.v. & $2-4 \mathrm{mg} / \mathrm{kg} / 24 \mathrm{~h}$ & $150 \mathrm{mg} / 24 \mathrm{~h}$ & $\begin{array}{l}\text { Invasive candidiasis. } \\
\text { Antifungal prophylaxis. } \\
\text { *Use if others antifungals are not } \\
\text { appropriate. }\end{array}$ \\
\hline Anidulafungin & i.v. & $1.5 \mathrm{mg} / \mathrm{kg} / 24 \mathrm{~h}$ & $100 \mathrm{mg} / 24 \mathrm{~h}$ & \\
\hline Fluconazole & i.v., oral & $6-12 \mathrm{mg} / \mathrm{kg} / 24 \mathrm{~h}$ & $200-400 \mathrm{mg} / 24 \mathrm{~h}$ & $\begin{array}{l}\text { Invasive and superficial candidiasis. } \\
\text { Antifungal prophylaxis. }\end{array}$ \\
\hline Voriconazole & i.v., oral & $7 \mathrm{mg} / \mathrm{kg} / 12 \mathrm{~h}$ & $4 \mathrm{mg} / \mathrm{kg} / 12 \mathrm{~h}$ & $\begin{array}{l}\text { Invasive aspergillosis, candidiasis, } \\
\text { scedosporiosis and fusariosis. }\end{array}$ \\
\hline Posaconazole & oral & Not available & $400 \mathrm{mg} / 12 \mathrm{~h}$ & \\
\hline Itraconazole & i.v., oral & $3-10 \mathrm{mg} / \mathrm{kg} / 24 \mathrm{~h}$ & $100-200 \mathrm{mg} / 24 \mathrm{~h}$ & \\
\hline
\end{tabular}

AmB-D: amphotericin B deoxycholate, AmB-LC: amphotericin B lipid complex, L-AmB: liposomal amphotericin B, iv: intravenously. mg: milligram. kg: kilograms. m: meter. h: hour.

\subsection{Echinocandins}

In children, caspofungin is currently approved as a treatment for invasive candidiasis, treatment of IA refractory to other antifungal agents as well as for empirical therapy in neutropenic patients. In children under 16 years, micafungin is approved for the treatment of invasive candidiasis and prophylaxis of Candida infection in patients undergoing allo-HSCT or with neutropenia expected for more than 10 days, while anidulafungin has not been approved in children although Cohen-Wolkowiez et al. performed a study showing that children who received $1.5 \mathrm{mg} / \mathrm{kg} /$ day reached levels similar to adults receiving $100 \mathrm{mg} / \mathrm{kg} /$ day $^{[50]}$.

\subsection{Amphotericin B}

Renal impairment is a strong limitation for amphotericin B deoxicholate ${ }^{[51]}$ and should not be routinely used in children. Amphotericin B lipid complex and, especially, liposomal amphotericin B (L-AmB) have less renal toxicity. Infusion 
related side effects are substantially less frequent only with L-AmB. Now, L-AmB is approved for empirical therapy in persistently neutropenic patients and for invasive mycoses treatment, being the treatment drug of choice for invasive mucormycosis ${ }^{[52]}$.

\section{Treatment}

Four different approaches are available for the clinical management of IFD: prophylaxis and three types of therapy -empiric, preemptive and targeted-. We should use the most appropriate in every patient. In all approaches, we have to evaluate the benefit, cost and potential side effects of the chosen drug. There is another important issue: the knowledge of the most prevalent IFD in our institution and its sensibility to different antifungal drugs. In the list below children are divided according to the risk for fungal infection and in Figures 3 and Figure 4 we present an algorithm to approach management of these hematological pediatric patients.

\section{HIGH-RISK}

- Allogeneic hematopoietic stem cell transplantation.

- Acute myeloid leukemia: induction or consolidation chemotherapy.

- Acute lymphoblastic leukemia: reinduction chemotherapy.

- Aplastic anemia (expected $<200 / \mathrm{mm}^{3}$ neutrophil count $>14$ days).

\section{LOW-RISK}

- Autologous hematopoietic stem cell transplantation.

- Acute lymphoblastic leukemia: induction chemotherapy.

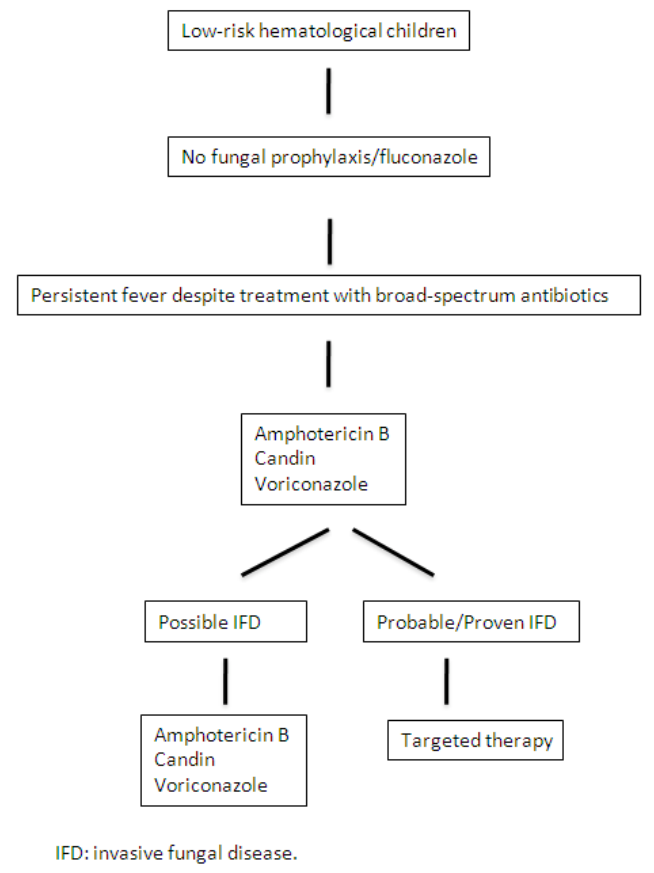

Figure 3. Proposed algorithm for the management of children with hematological diseases and low-risk of fungal infection 


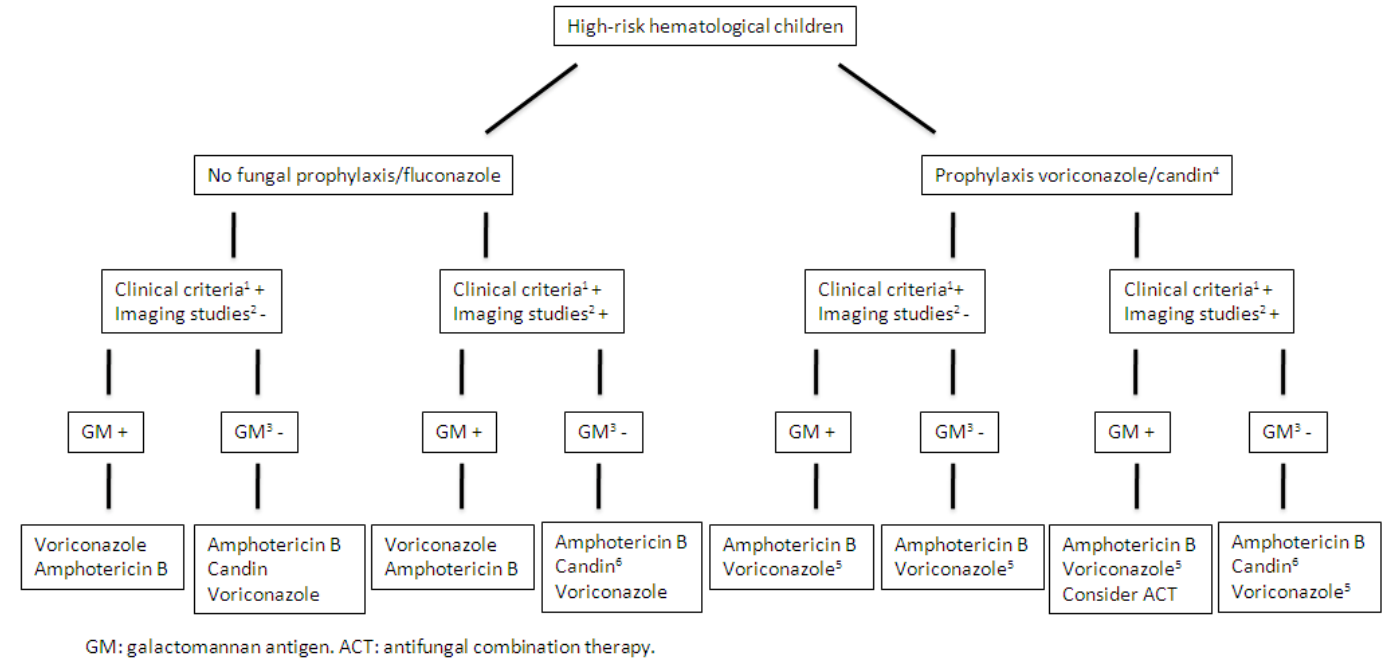

Figure 4. Proposed algorithm for the management of children with hematological diseases and high-risk of fungal infection.

1. Clinical criteria: persistent fever despite treatment with broad-spectrum antibiotics.

2. Computed tomography scan, ultrasound, nuclear magnetic resonance.

3. GM-: GM negative or not available.

4. Micafungin is the only echinocandin with indication for prophylaxis.

5. Consider using voriconazole if the patient is receiving a prophylaxis with an echinocandin.

6. If imaging studies are compatible with IFD caused by filamentous fungi you should not use an echinocandin in monotherapy.

* Voriconazole is not approved for children under 2 years and caspofungin is not approved for children under 1 year.

\subsection{Prophylaxis}

Prophylaxis should be used in patients at risk of IFD. Many centers have conducted additional prophylaxis trials aiming to reduce the incidence and mortality of IFD $^{[33-55]}$ after allo-HSCT, but children are frequently excluded due to lack of an appropriately characterized or unknown dosage. For years, fluconazole has been the gold standard drug for prophylaxis in hematological patients undergoing aggressive chemotherapy or stem cell transplantation ${ }^{[56]}$. Dvorak et al. performed a study using Amphotericin B deoxicholate or fluconazole as antifungal prophylaxis with an IFD rate of $13 \%{ }^{[57]}$. Mehta et al. reported 15 pediatric patients who received antifungal prophylaxis with micafungin ( $3 \mathrm{mg} / \mathrm{kg} / 48$ hours), the drugs reached good serum levels and no patient developed IFD ${ }^{[58]}$. Kolve et al. used L-AmB as primary or secondary prophylaxis in children (3.5\% IFD in the global series) ${ }^{[59]}$ and van Burik et al. used micafungin only during neutropenic phase $\left(2.5 \%\right.$ of IFD) ${ }^{[60]}$. Mandhaniya et al. prospectively compared oral voriconazole $(4 \mathrm{mg} / \mathrm{kg} / 12$ hours $)$ versus intravenous low dose of conventional amphotericin B $(0.5 \mathrm{mg} / \mathrm{kg} /$ day thrice weekly) as primary antifungal prophylaxis in pediatric acute leukemia (both lymphoblastic and myeloid) induction. Voriconazole was comparable with amphotericin B with less toxicity and more convenience ${ }^{[61]}$.

We recently published a series of 56 children undergoing allo-HSCT using primary prophylaxis with voriconazole (5 $\mathrm{mg} / \mathrm{kg} / 12$ hours or $7 \mathrm{mg} / \mathrm{kg} / 12$ hours), only one of them with acute graft versus host disease developed IFD (probable aspergillosis) on day +130 , but $10(17.8 \%)$ patients presented adverse effects related to voriconazole, easily resolved once the drug was stopped ${ }^{[62]}$. Compared to our previous strategy, using fluconazole prophylaxis, the incidence of IFD, from January 2000 to October 2004, in pediatric patients who underwent allo-HSCT was significantly higher than with voriconazol prophylaxis ( $12.1 \%$ vs. $1.8 \%, p=.03)$. A total of 33 children received an Allo-HSCT in this time; four of them developed IFD: three pulmonary aspergillosis and one invasive candidiasis, with a mortality of $75 \%$. Similarly, we published our results using Voriconazol as primary antifungal prophylaxis in patients with neutropenia after HSCT or chemotherapy for acute myeloid leukemia ${ }^{[54]}$, including $16 \%$ of pediatric patients, showing an overall treatment success 
rate of $72.9 \%$, with a reduced use of empirical therapy (17\%), and in contrast to data described by Trifilio et al. ${ }^{[15]}$, we did not find an increase of breakthrough zygomycosis.

Wingard et al. compared fluconazole with voriconazole in patients (including children) who had undergone allo-HSCT and differences did not reached statistical significance in terms of IFD incidence, but they did not study children separately from adults ${ }^{[63]}$. Ullman et al. conducted a randomized study that showed that posaconazole was superior in preventing IA and reducing the rate of deaths related to fungal infections in patients with graft versus host disease ${ }^{[5]}$, while Cornely et al. indicated that in patients undergoing chemotherapy for acute myeloid leukemia or myelodisplastic syndrome, posaconazole prevented fungal infections more effectively than did either fluconazole or itraconazole but with more serious adverse events ${ }^{[64]}$. However, in both studies children under 13 years were not included.

\subsection{Empirical treatment}

Empirical treatment is used in high-risk children with persistent or recurrent fever despite broad-spectrum antibiotic therapy, without radiological or microbiological evidence of IFD. There is only a randomized, double blind, multicenter trial published comparing caspofungin with L-AmB for empirical antifungal therapy in 82 pediatric patients (60 with hematological diseases) with persistent fever and neutropenia without differences in safety and efficacy ${ }^{[65]}$. Recently, Caselli et al. conducted a randomized study that evaluated empirical antifungal therapy in 110 neutropenic children with persistent fever and found high-risk patients as the target for empirical antifungal therapy in contrast to the low-risk ${ }^{[66]}$. Koo et al. evaluated the efficacy and safety of caspofungin for the empirical treatment in neutropenic children, $79 \%$ of courses resulted in a favourable response while $25 \%$ of courses experienced an adverse-drug-related event attributed to caspofungin ${ }^{[67]}$.

\subsection{Preemptive treatment}

There are no studies addressing preemptive therapy for IFD in children with hematological diseases, so this approach should be not recommended in pediatric patients. The most important work about this issue was published by Maertens et al. who called for early initiation of antifungal therapy, while reducing empirical therapy, using GM and Computed Tomography for early diagnosis, but all patients were older than 16 years ${ }^{[68]}$. Subsequently, Cordonnier et al. compared empiric versus preemptive antifungal treatment in a multicenter, open-label, randomized trial in patients over 18 years and it was found that preemptive treatment increased the incidence of IFD without increasing mortality ${ }^{[69]}$. Pagano et al. had similar results when comparing preemptive vs. empiric antifungal therapy, but in this study children were not included ${ }^{[70]}$. Finally, Tan et al. in a study in 52 episodes in high-risk hematological patients concluded that a preemptive approach may reduce empirical antifungal use without differences in twelve-week survival rates in persistently febrile neutropenic patients, but this work did not include children ${ }^{[71]}$. We rarely use preemptive therapy because of the high false positive rate of GM and Aspergillus PCR.

\subsection{Targeted therapy}

Once an IFD has been diagnosed, we must initiate targeted therapy. The choice of specific drug relies on several variables: the antifungal drug used for prophylaxis or empirical treatment, the patient's clinical conditions, type of fungal infection and sensitivity of fungi to different antifungals in each institution. We have considered that one of the main points is the restoration of the host immune response, particularly in our experience granulocyte recovery ${ }^{[72]}$ joined to an early and appropriate treatment ${ }^{[73]}$.

International guidelines recommend using an echinocanin or lipids formulations of amphotericin B, particularly L-AmB because of its lower rate of side effects, in children with invasive candidiasis while voriconazole can be used when additional coverage for molds is desired ${ }^{[74]}$. Recently, several non-albicans Candida species are occurring with increasing frequency ${ }^{[75]}$ : especially Candida glabrata that should preferably be treated with an echinocandin, and Candida krusei, which can be treated with an echinocandin, L-AmB or voriconazole. 
In contrast to adult patients, prospective randomized studies have not been performed in children with hematological malignancies and diagnosed with IA. Nevertheless, children have been placed together with adults in published studies, but unfortunately in most of them, children has not been analyzed separately from adults and, in addition, not all patients in the studies were diagnosed with hematologic diseases. Voriconazole is currently the first-line treatment of choice for IA based on the data reported by Herbrecht et al. that established the significant superiority of voriconazole vs. amphotericin $\mathrm{B}$ in patients with $\mathrm{IA}^{[76]}$. L-AmB is also a valid treatment option for IA and caspofungin may be used in children who are refractory or intolerant to other antifungal agents ${ }^{[77]}$.

Table 2. Targeted therapy of Invasive Fungal Disease in children

\begin{tabular}{|c|c|c|}
\hline Fungal Infection & First-line treatment & Second-line treatment \\
\hline $\begin{array}{l}\text { Oropharyngeal } \\
\text { Candidiasis }\end{array}$ & Fluconazole $6-12 \mathrm{mg} / \mathrm{kg} / 24 \mathrm{~h}$ & L-AmB $3 \mathrm{mg} / \mathrm{kg} / 24 \mathrm{~h}$ \\
\hline Candidemia & $\begin{array}{l}\text { Fluconazole } 6-12 \mathrm{mg} / \mathrm{kg} / 24 \mathrm{~h} \\
\text { Caspofungin } 50 \mathrm{mg} / \mathrm{m}^{2} / 24 \mathrm{~h} \\
\text { Micafungin } 4 \mathrm{mg} / \mathrm{kg} / 24 \mathrm{~h} \\
\mathrm{~L}-A m B 3 \mathrm{mg} / \mathrm{kg} / 24 \mathrm{~h}\end{array}$ & $\begin{array}{l}\text { Voriconazole } 7 \mathrm{mg} / \mathrm{kg} / 12 \mathrm{~h} \\
\text { Antifungal combination therapy }\end{array}$ \\
\hline $\begin{array}{l}\text { Hepatoesplenic } \\
\text { Candidiasis }\end{array}$ & $\begin{array}{l}\mathrm{L}-\mathrm{AmB} 3 \mathrm{mg} / \mathrm{kg} / 24 \mathrm{~h} \\
\text { Caspofungin } 50 \mathrm{mg} / \mathrm{m}^{2} / 24 \mathrm{~h} \\
\text { Micafungin } 4 \mathrm{mg} / \mathrm{kg} / 24 \mathrm{~h} \\
\text { Voriconazole } 7 \mathrm{mg} / \mathrm{kg} / 12 \mathrm{~h}\end{array}$ & \\
\hline $\begin{array}{l}\text { Invasive } \\
\text { Aspergillosis } \\
\text { (pulmonary, } \\
\text { sinusal, cerebral, } \\
\text { cutaneous...) }\end{array}$ & Voriconazole $7 \mathrm{mg} / \mathrm{kg} / 12 \mathrm{~h}$ & $\begin{array}{l}\mathrm{L}-\mathrm{AmB} 3 \mathrm{mg} / \mathrm{kg} / 24 \mathrm{~h} \\
\text { Caspofungin } 50 \mathrm{mg} / \mathrm{m}^{2} / 24 \mathrm{~h} \\
\text { Antifungal combination therapy }\end{array}$ \\
\hline $\begin{array}{l}\text { Mucormycosis } \\
\text { (pulmonary, } \\
\text { rhinosinusal, } \\
\text { cerebral...) }\end{array}$ & $\mathrm{L}-\mathrm{AmB} 3 \mathrm{mg} / \mathrm{kg} / 24 \mathrm{~h}$ & $\begin{array}{l}\text { Posaconazole } 400 \mathrm{mg} / \text { twice daily (not recommended } \\
\text { in children under } 13 \text { years) } \\
\text { Antifungal combination therapy }\end{array}$ \\
\hline Fusariosis & $\begin{array}{l}\text { Voriconazole } 7 \mathrm{mg} / \mathrm{kg} / 12 \mathrm{~h} \\
\text { L-AmB } 3 \mathrm{mg} / \mathrm{kg} / 24 \mathrm{~h}\end{array}$ & \\
\hline Scedosporiosis & $\begin{array}{l}\text { Voriconazole } 7 \mathrm{mg} / \mathrm{kg} / 12 \mathrm{~h} \\
\mathrm{~L}-\mathrm{AmB} 3 \mathrm{mg} / \mathrm{kg} / 24 \mathrm{~h}\end{array}$ & \\
\hline
\end{tabular}

L-AmB: liposomal amphotericin B, mg: milligram. kg: kilograms. m: meter. h: hour.

L-AMB is the drug of choice for invasive mucormycosis whereas posaconazole can be used as rescue therapy or when L-AmB should be discontinued because of unacceptable adverse effects. This therapy must be supplemented with an early surgical debridement of affected tissues ${ }^{[52]}$ and local therapy as amphotericin B ointment or instillation ${ }^{[78]}$. Since 2004 we have only diagnosed a rhino-orbital mucormycosis in a 13 year old boy with aplastic anemia successfully resolved by surgical treatment, L-AmB and posaconazole. Voriconazole and L-AmB are the drugs of choice for the treatment of invasive infection caused by Fusarium spp. ${ }^{[79]}$ and Scedosporium spp. ${ }^{[80]}$, whereas posaconazole can be used as salvage therapy for these infections. In Table 2 are summarized the targeted therapy of most important fungal infections. 


\subsection{Combined antifungal therapy}

There are no randomized trials comparing monotherapy versus combination antifungal therapy in pediatric population. Although international guidelines do not recommend it ${ }^{[81]}$, the availability of new agents with different modes of action has led to use them in combination for selected patients, particularly the combination of an echinocandin with a mold-active azole or L-AmB with promising results ${ }^{[22-84]}$. We recently published a retrospective study in hematological patients diagnosed with IFD and treated with antifungal combination therapy. This study included children and $62 \%$ of patients achieved a favourable response whatever the combination antifungal used ${ }^{[72]}$. By contrast, Kontoyiannis et al. conducted a study in patients with IA treated with micafungin alone or in combination with other antifungals reporting a response rate of $26 \%$ and $19 \%$ in the global series and in the pediatric population, respectively ${ }^{[85]}$. Mihu et al. reported a retrospective study in 159 hematological pediatric and adult patients and they found that the combination of L-AmB and echinocandins did not offer advantage over either drug alone ${ }^{[86]}$. A randomized clinical trial in adult patients with hematological diseases or undergoing stem cell transplantation is now completed and will provide more insights on the general usefulness of antifungal combinations in first line therapy ${ }^{[87]}$. A study in children using voriconazole plus anidulafungin for IA has been withdrawn ${ }^{[88]}$.

\subsection{Adjuvant therapy}

Despite the availability of new antifungal compounds, morbidity and mortality of IFD, particularly in pediatric Allo-HSCT recipients remains unacceptably high. The past decade has witnessed an exciting improvement of the understanding of the molecular pathogenesis and the complexity of host antifungal immune responses. Strategies for enhancing the immune system include the administration of effector cells (e.g., granulocytes, antigen-specific $\mathrm{T}$ cells, dendritic cells) as well as the administration of recombinant cytokines, interferons and growth factors (e.g., interferon- $\gamma$, keratinocyte growth factor, granulocyte and granulocyte-macrophage colony stimulating factor). In this sense, granulocytes transfusion has been used in neutropenic patients with aspergillosis, despite the lack of evidence of safety, efficacy and appropriate doses ${ }^{[89]}$.

In pediatric patients with hematologic malignancies and diagnosed with IFD another adjuvant therapies can improve survival outcome; in children with hepatoesplenic candidiasis the use of corticosteroids added to antifungal drug as a treatment for immune reconstitution inflammatory syndrome, is associated with prompt resolution of the symptoms once neutrophil recovery occurs ${ }^{[90,91]}$.

Iron chelation with deferasirox was a promising adjuvant therapy in adults ${ }^{[92]}$ but Spellberg et al. observed that patients with mucormycosis treated with deferasirox and L-AmB had a higher mortality rate at 90 days and concluded that these data do not support a role for initial adjunctive deferasirox therapy for mucormycosis ${ }^{[93]}$. Hyperbaric oxygen is another adjuvant therapy for mucormycosis but clinical data are very limited ${ }^{[94]}$.

\section{Future directions}

\subsection{Nonstandard diagnostic techniques}

In addition to detection of fungal cell wall components ( $\beta$-glucan and galactomannan) and fungal-related nucleic acids, newer nonculture-based assays are being investigated to improve the early diagnosis of IFD caused by Candida, 
Aspergillus and other fungal pathogens. These methods include antibodies or antigens (e.g., mannan) and metabolites (e.g., L/D-arabinitol) ${ }^{[95]}$. It has begun to explore whether diagnosis can be improved by a combination of both methods ${ }^{[96]}$.

\subsection{Host susceptibility to invasive fungal disease}

There is a large body of evidence that there is a genetic component leading to the susceptibility and outcome of IFD in immunocompromised patients. In allo-HSCT recipients, several genes polymorphisms in both host and donor, has been described to significantly predispose patients to IFD (TLR1 \& TLR6; IL-10 promoter; Plasminogen; TLR4; Chemokine Ligand 10; Dectin-1) ${ }^{[97]}$. Future research will likely discover additional polymorphisms that lead immunocompromised hosts at an increased risk of IFD.

\subsection{I nvestigational antifungal agents}

In parallel with the rise in the frequency and spectrum of IFD, several new antifungal agents have been developed. These agents optimally should reduce toxicity, improve bioavailability and overcome resistance to conventional drugs. Most data of investigational antifungal agents such as albaconazole, isavuconazole, ravuconazole, aminocandin, MK-3118 and E1210 are limited to animal studies or Phase I/II studies in humans ${ }^{[98-100]}$. As common features, these antifungal agents share extended half-lives, good tolerance and low drug interaction profiles. In addition to activity against Candida and Aspergillus spp., they have a broad spectrum activity against resistant and emerging pathogens. However, adequate randomized clinical trials will provide more information to assess the real potential of these agents in the future.

\section{Conclusions}

Invasive Fungal Disease is a life-threatening infection in patients with hematological malignancies or undergoing stem cell transplantation. An accurate definition of risk, an aggressive diagnostic approach and an effective and proper use of different types of treatment should lead to a progressive success in solving these serious complications in adults and children, without forgetting that children are not small adults, so we need to know the main differences in the diagnosis and treatment of IFD in both.

\section{Competing interests}

JR. Molina has received honoraria for speaking at medical education events supported by Gilead Science and Pfizer. R. Rojas has received honoraria for speaking at medical education events supported by Gilead Science and Merck Sharp \& Dohme (MSD). J. Serrano and P. Gómez declare no competing financial interest.

\section{References}

[1] McNeil MM, Nash SL, Hajjeh RA, Phelan MA, Conn LA, Plikaytis BD et al. Trends in mortality due to invasive mycotic diseases in the United States, 1980-1997. Clin Infect Dis. 2001; 33(5): 641-647. PMid:11486286 http://dx.doi.org/10.1086/322606

[2] Zaoutis TE, Argon J, Chu J, Berlin JA, Walsh TJ, Feudtner C. The epidemiology and attributable outcomes of candidemia in adults and children hospitalized in the United States: a propensity analysis. Clin Infect Dis. 2005; 41(9): 1232-1239. PMid:16206095 http://dx.doi.org/10.1086/496922

[3] Cugno C, Cesaro S. Epidemiology, risk factors and therapy of candidemia in pediatric hematological patients. Pediatr Rep. 2012; 4(1): e9. PMid:22690315 http://dx.doi.org/10.4081/pr.2012.e9

[4] Walsh TJ, Pappas P, Winston DJ, Lazarus HM, Petersen F, Raffalli J et al. Voriconazole compared with liposomal amphotericin B for empirical antifungal therapy in patients with neutropenia and persistent fever. N Engl J Med. 2002; 346(4): $225-234$. PMid:11807146 http://dx.doi.org/10.1056/NEJM200201243460403

[5] Benjamin DK Jr, Driscoll T, Seibel NL, Gonzalez CE, Roden MM, Kilaru R et al. Safety and Pharmacokinetics of Intravenous Anidulafungin in Children with Neutropenia at High Risk for Invasive Fungal Infections. Antimicrob Agents Chemother. 2006; 50(2): 632-638. PMid:16436720 http://dx.doi.org/10.1128/AAC.50.2.632-638.2006 
[6] Rocha V, Gluckman E. Eurocord and European Blood and Marrow Transplant Group. Clinical use of umbilical cord blood hematopoietic stem cells. Biol Blood Marrow Transplant. 2006; 12(1 Suppl): S134-141. PMid:16399582 http://dx.doi.org/10.1016/j.bbmt.2005.09.006

[7] Griffin TC, Weitzman S, Weinstein H, Chang M, Cairo M, Hutchison R et al. A study of rituximab and ifosfamide, carboplatin, and etoposide chemotherapy in children with recurrent/refractory B-cell (CD20+) non-Hodgkin lymphoma and mature B-cell acute lymphoblastic leukemia: a report from the Children's Oncology Group. Pediatr Blood Cancer. 2009; 52(2): 177-181. http://dx.doi.org/10.1002/pbc.21753

[8] Hale KA, Shaw PJ, Dalla-Pozza L, MacIntyre CR, Isaacs D, Sorrell TC. Epidemiology of paediatric invasive fungal infections and a case-control study of risk factors in acute leukaemia or post stem cell transplant. Br J Haematol. 2010; 149(2): $263-272$. PMid:20096013 http://dx.doi.org/10.1111/j.1365-2141.2009.08072.x

[9] Rubio PM, Sevilla J, Gonzalez-Vicent M, Lassaletta A, Cuenca-Estrella M, Díaz MA et al. Increasing incidence of invasive aspergillosis in pediatric hematology oncology patients over the last decade: a retrospective single centre study. J Pediatr Hematol Oncol. 2009; 31(9): 642-646. PMid:19684521 http://dx.doi.org/10.1097/MPH.0b013e3181acd956

[10] Hernández-Marqués C, Lassaletta-Atienza A, González-Vicent M, Sevilla J, Molina B, Andión M et al. Hepatosplenic candidiasis in paediatric haematology-oncology patients. An Pediatr. 2011; 75(1): 26-32.

[11] Pfaller MA, Diekema DJ. Epidemiology of invasive candidiasis: a persistent public health problem. Clin Microbiol Rev. 2007; 20(1): 133-163. PMid:17223626 http://dx.doi.org/10.1128/CMR.00029-06

[12] Pappas PG. Invasive candidiasis. Infect Dis Clin North Am. 2006; 20(39): 485-506. PMid:16984866 http://dx.doi.org/10.1016/j.idc.2006.07.004

[13] Burgos A, Zaoutis TE, Dvorak CC, Hoffman JA, Knapp KM, Nania JJ et al. Pediatric invasive aspergillosis: a multicenter retrospective analysis of 139 contemporary cases. Pediatrics. 2008; 121(5): e1286-1294. PMid:18450871 http://dx.doi.org/10.1542/peds.2007-2117

[14] Groll AH, McNeil Grist L. Current challenges in the diagnosis and management of invasive fungal infections: report form the 15th International Symposium of Infections in the Immunocompromised Host: Thessaloniki, Greece, 22-25 June 2008. Int J Antimicrob Agents. 2009; 33(2): 101-104. PMid:19008080 http://dx.doi.org/10.1016/j.ijantimicag.2008.08.014

[15] Trifilio SM, Bennett CL, Yarnold PR, McKoy JM, Parada J, Mehta J et al. Breakthrough zygomycosis after voriconazole administration among patients with hematological malignancies who receive hematopoietic stem-cell transplants or intensive chemotherapy. Bone Marrow Transplant. 2007; 39(7): 425-429. PMid:17310132 http://dx.doi.org/10.1038/sj.bmt.1705614

[16] Lekakis LJ, Lawson A, Prante J, Ribes J, Davis GJ, Monohan G et al. Fatal rhizopus pneumonia in allogeneic stem cell transplant patients despite posaconazole prophylaxis: two cases and review of the literature. Biol Blood Marrow Transplant. 2009; 15(8): 991-995. PMid:19589489 http://dx.doi.org/10.1016/j.bbmt.2009.04.007

[17] Kontoyiannis DP, Marr KA, Park BJ, Alexander BD, Anaissie EJ, Walsh TJ et al. Prospective surveillance for invasive fungal infections in hematopoietic stem cell transplant recipients, 2001-2006: overview of the Transplant-Associated Infection Surveillance Network (TRANSNET) Database. Clin Infect Dis. 2010; 50(8): 1091-1100. PMid:20218877 http://dx.doi.org/10.1086/651263

[18] Steinbach WJ. Pediatric aspergillosis: disease and treatment differences in children. Pediatr Infect Dis J. 2005; 24(4): $358-364$. PMid:15818297 http://dx.doi.org/10.1097/01.inf.0000157218.37603.84

[19] Thomas L, Baggen L, Chisholm J, Sharland M. Diagnosis and treatment of aspergillosis in children. Expert Rev Anti Infect Ther. 2009; 7(4): 461-472. PMid:19400765 http://dx.doi.org/10.1586/eri.09.19

[20] Freifeld AG, Bow EJ, Sepkowitz KA, Boeckh MJ, Ito JO, Mullen CA et al. Clinical practice Guideline for the use of antimicrobial agents in neutropenic patients with cancer: 2010 Update by the Infectious Diseases Society of America. Clin Infect Dis. 2011; 52(4): e56-93. PMid:21258094 http://dx.doi.org/10.1093/cid/cir073

[21] Barberan J, Mensa J, Vallejo JC, Jarque I, García JC, Cabrera JR et al. Recommendations for the treatment of invasive fungal infection caused by filamentous fungi in the hematological patient. Rev Esp Quimioter. 2011; 24(4): 263-270. PMid:22173196

[22] Pearce MS, Salotti JA, Little MP, McHugh K, Lee C, Kim KP et al. Radiation exposure from CT scans in childhood and subsequent risk of leukaemia and brain tumours: a retrospective cohort study. Lancet. 2012. http://dx.doi.org/10.1016/S0140-6736(12)60815-0

[23] Bochennek K, Abolmaali N, Wittekindt B, Schwabe D, Klingebiel T, Lehrnbecher T. Diagnostic approaches for immunocompromised paediatric patients with pulmonary infiltrates. Clin Microbiol Infect. 2006; 12(3): 199-201. PMid:16451404 http://dx.doi.org/10.1111/j.1469-0691.2005.01316.x

[24] Berenguer J, Buck M, Witebsky F, Stock F, Pizzo PA, Walsh TJ. Lysis-centrifugation blood cultures in the detection of tissue-proven invasive candidiasis. Disseminated versus single-organ infection. Diagn Microbiol Infect Dis. 1993; 17(2): $103-109$. http://dx.doi.org/10.1016/0732-8893(93)90020-8 
[25] de Pauw B, Walsh TJ, Donnelly JP, Stevens DA, Edwards JE, Calandra T et al. Revised definitions of invasive fungal disease from the European Organization for Research and Treatment of Cancer/Invasive Fungal Infections Cooperative Group and the National Institute of Allergy and Infectious Diseases Mycosis Study Group (EORTC/MSG) Consensus Group. Clin Infect Dis. 2008; 46(12): 1813-1821. PMid:18462102 http://dx.doi.org/10.1086/588660

[26] Maertens J, Verhaegen J, Lagrou K, Van Eldere J, Boogaerts M. Screening for cir- culating galactomannan as a noninvasive diagnostic tool for invasive aspergillosis in prolonged neutropenic patients and stem cell transplantation recipients: a prospective validation. Blood. 2001; 97(6): 1604-1610. PMid:11238098 http://dx.doi.org/10.1182/blood.V97.6.1604

[27] Sulahian A, Touratier S, Ribaud P. False positive test for aspergillus antigenemia related to concomitant administration of piperacillin and tazobactan. N Engl J Med. 2003; 349(24): 2366-2367. PMid:14668472 http://dx.doi.org/10.1056/NEJM200312113492424

[28] Bart-Delabesse E, Basile M, Al Jijakli A, Souville D, Gay F, Philippe B et al. Detection of Aspergillus galactomannan antigenemia to determine biological and clinical implications of beta-lactam treatments. J Clin Microbiol. 2005; 43(10): 5214-5220. PMid:16207986 http://dx.doi.org/10.1128/JCM.43.10.5214-5220.2005

[29] Gangneux JP, Lavarde D, Bretagne S, Guiguen C, Gandemer V. Transient aspergillus antigenaemia: think of milk. Lancet. 2002; 359(9313): 1251. http://dx.doi.org/10.1016/S0140-6736(02)08238-7

[30] Mennink-Kersten MA, Ruegebrink D, Klont RR, Warris A, Gavini F, Op den Camp HJ et al. Bifidobacterial lipoglycan as a new cause for false-positive platelia Aspergillus enzyme-liked immunosorbent assay reactivity. J Clin Microbiol. 2005; 43(8): 3925-3931. PMid:16081932 http://dx.doi.org/10.1128/JCM.43.8.3925-3931.2005

[31] Marr KA, Laverdiere M, Gugel A, Leisenring W. Antifungal decreases sensitivity of the Aspergillus galactomannan enzyme immunoassay. Clin Infect Dis. 2005; 40(12): 1762-1769. PMid:15909264 http://dx.doi.org/10.1086/429921

[32] Steinbach WJ, Addison RM, McLAughlin L, Gerrald Q, Martin PL, Driscoll T et al. Prospective aspergillus galactomannan antigen testing in pediatric hematopoietic stem cell transplant recipients. Pediatr Infect Dis J. 2007; 26(7): 558-564. PMid:17596794 http://dx.doi.org/10.1097/INF.0b013e3180616cbb

[33] Hayden R, Pounds S, Knapp K, Petraitiene R, Schaufele RL, Sein T et al. Galactomannan antigenemia in pediatric oncology patients with invasive aspergillosis. Pediatr Infect Dis J. 2008; 27(9): 815-819. PMid:18703991 http://dx.doi.org/10.1097/INF.0b013e31817197ab

[34] Castagnola E, Furfaro E, Caviglia I, Licciardello M, Faraci M, Floredda F et al. Performance of the galactomannan antigen detection test in the diagnosis of invasive aspergillosis in children with cancer or undergoing haematopoietic stem cell transplantation. Clin Microbiol Infect. 2010; 16(8): 1197-1203. PMid:20156215 http://dx.doi.org/10.1111/j.1469-0691.2009.03065.x

[35] Sulahian A, Tabouret M, Ribaud P, Sarfati J, Gluckman E, Latge JP et al. Comparison of an enzyme immunoassay and a latex agglutination test for detection of galactomannan in the diagnosis of invasive aspergillosis. Eur J Clin Microbiol Infect Dis. 1996; 15(2): 139-145. PMid:6756909 http://dx.doi.org/10.1007/BF01591487

[36] Mennink-Kersten MA, Donnelly JP, Verweij PE. Detection of circulating galactomannan for the diagnosis and management of invasive aspergillosis. Lancet Infec Dis. 2004; 4(6): 349-357. http://dx.doi.org/10.1016/S1473-3099(04)01045-X

[37] Smith PV, Benjamin DK, Alexander BD, Johnson MD, Finkelman MA, Steinbach WJ. Quantification of 1,3-beta-D-glucan levels in children: preliminary data for diagnostic use of the beta-glucan assay in a pediatric setting. Clin Vaccine Immunol. 2007; 14(7): 924-925. PMid:17538119 http://dx.doi.org/10.1128/CVI.00025-07

[38] Mokaddas E, Burhamah MH, Khan ZU, Ahmad S. Levels of (1-3)-Beta-D-glucan, Candida mannan and Candida DNA in serum samples of pediatric cancer patients colonized with Candida species. BMC Infect Dis. 2010; 10: 292. PMid:20923575 http://dx.doi.org/10.1186/1471-2334-10-292

[39] Hummel M, Spiess B, Roder J, von Komorowski G, Dürken M, Kentouche K et al. Detection of Aspergillus DNA by a nested PCR assay is able to improve the diagnosis of invasive aspergillosis in paediatric patients. J Med Microbiol. 2009; 58(pt10): $1291-1297$. PMid:19541789 http://dx.doi.org/10.1099/jmm.0.007393-0

[40] Armenian SH, Nash KA, Kapoor N, Franklin JL, Gaynon PS, Ross LA et al. Prospective monitoring for invasive aspergillosis using galactomannan and polumerase chain reaction in high risk pediatic patients. J Pediatr Hematol Oncol. 2009; 31(12): $920-926$. PMid:19855303 http://dx.doi.org/10.1097/MPH.0b013e3181b83e77

[41] El-Mahallawy HA, Shaker HH, Ali Helmy H, Mostafa T and Razak Abo-Sedah A. Evaluation of pan-fungal PCR assay and Aspergillus antigen detection in the diagnosis of invasive fungal infection in high risk paediatric cancer patients. Med Mycol. 2006; 44(8): 733-739. PMid:17127630 http://dx.doi.org/10.1080/13693780600939955

[42] Landlinger C, Preuner S, Baskova L, van Grotel M, Hartwig NG, Dworzak M et al. Diagnosis of invasive fungal infections by a real-time panfungal PCR assay in immunocompromised pediatric patients. Leukemia. 2010; 24(12): 2032-2038. PMid:20882044 http://dx.doi.org/10.1038/leu.2010.209 
[43] Karthaus M, Huebner G, Geissler RG, Heil G, Ganser A. Hepatic lesions of chronic disseminated systemic candidiasis in leukemia patients may become visible during neutropenia: value of serial ultrasound examinations. Blood. 1998; 91(8): $3087-3089$. PMid:9531625

[44] Semelka RC, Kelekis NL, Sallah S, Worawattanakul S, Ascher SM. Hepatosplenic fungal disease: diagnostic accuracy and spectrum of appearances on MR imaging. AJR Am J Roentgeno. 1997; 169(5): 1311-1316. PMid:9353448

[45] Lehrnbecher T, Attarbaschi A, Duerken M, Garbino J, Gruhn B, Kontny U et al. Posaconazole salvage treatment in paediatric patients: a multicenter survey. Eur J Clin Microbiol Infect Dis. 2010; 29(8): 1043-1045. PMid:6756909 http://dx.doi.org/10.1007/s10096-010-0957-4

[46] Cesaro S, Milano GM, Aversa F. Retrospective survey on the off-label use of posaconazole in pediatric hematology patients. Eur J Clin Microbiol Infect Dis. 2011; 30(4): 595-596. PMid:6756909 http://dx.doi.org/10.1007/s10096-010-1123-8

[47] Kobayashi R, Suzuki D, Yaasuda K, Kobayashi K. Itraconazole for invasive fungal infection with pediatric malignancies. Pediatr Int. 2010; 52(5); 707-710. PMid:20337979 http://dx.doi.org/10.1111/j.1442-200X.2010.03127.x

[48] Bermudez M, Fuster JL, Llinares E, Galera A, Gonzalez C. Itraconazole-related increased vincristine neurotoxicity: case report and review of literarure. J Pediatr Hematol Oncol. 2005; 27(7): 289-292

[49] Sandherr M, Maschmeyer G. Pharmacology and metabolism of voriconazole and posaconazole in the treatment of invasive aspergillosos: review of the literature. Eur J Med Res. 2011; 16(4): 139-144 PMid:21486727 http://dx.doi.org/10.1186/2047-783X-16-4-139

[50] Cohen-Wolkowiez M, Benjamin DK Jr, Piper L, Cheifetz IM, Moran C, Liu P et al. Safety and pharmacokinetics of multiple-dose anidulafungin in infants and neonates. Clin Pharmacol Ther. 2011; 89(5): 702-707. http://dx.doi.org/10.1038/clpt.2011.26

[51] Goldman RD, Koren G. Amphotericin B nephrotoxicity in children. J Pediatr Hematol Oncol. 2004; 26(7); $421-426$. PMid:15218415 http://dx.doi.org/10.1097/00043426-200407000-00004

[52] Spellberg B, Walsh TJ, Kontoyiannis DP, Edwards J Jr, Ibrahim AS. Recent advances in the management of mucormycosis: from bench to bebside. Clin Infect Dis. 2009; 48(12): 1745-1751. PMid:19435437 http://dx.doi.org/10.1086/599105

[53] Marr KA, Crippa F, Leisenring W, Hoyle M, Boeckh M, Balajee SA et al. Itraconazole versus fluconazole for prevention of fungal infections in patients receiving allogeneic stem cell transplants. Blood. 2004; 103(4): 1527-1533. PMid:14525770 http://dx.doi.org/10.1182/blood-2003-08-2644

[54] Torres A, Serrano J, Rojas R, Martin V, Martin C, Tabares S et al. Voriconazole as primary antifungal prophylaxis in patients with neutropenia after hematopoietic stem cell transplantation or chemotherapy for acute myeloid leukemia. Eur J Haematol. 2010; 8 4(3): 371-373.

[55] Ullmann AJ, Lipton JH, Vesole DH, Chandrasekar P, Langston A, Tarantolo SR et al. Posaconazole or fluconazole for prophylaxis in severe graft-versus-host disease. N Engl J Med. 2007; 356(4): 335-347. PMid: 17251530 http://dx.doi.org/10.1056/NEJMoa061098

[56] Goodman JL, Winston DJ, Greenfield RA, Chandrasekar PH, Fox B, Kaizer H et al. A controlled trial of fluconazole to prevent fungal infections in patients undergoing bone marrow transplantation. N Engl J Med. 1992; 326(13): 845-851. PMid:1542320 http://dx.doi.org/10.1056/NEJM199203263261301

[57] Dvorak CC, Steinbach WJ, Brown JM, Agarwal R. Risks and outcomes of invasive fungal infections in pediatric patients undergoing allogeneic hematopoietic cell transplantation. Bone Marrow Transplant. 2005; 36(7): 621-629. PMid:16044133 http://dx.doi.org/10.1038/sj.bmt.1705113

[58] Mehta PA, Vinks AA, Filipovich A, Bleesing J, Jodele S, Jordan MB et al. Alternate-day micafungin antifungal prophylaxis in pediatric patients undergoing hematopoietic stem cell transplantation: a pharmacokinetic study. Biol Blood Marrow Transplant. 2010; 16(10): 1458-1462. PMid:20546908 http://dx.doi.org/10.1016/j.bbmt.2010.05.002

[59] Kolve H, Ahlke E, Fegeler W, Ritter J, Jurgens H, Groll AH. Safety, tolerance and outcome of treatment with liposomal amphotericin B in paediatric patients with cancer or undergoing haematopoietic stem cell transplantation. J Antimicrob Chemother. 2009; 64(2): 383-387. PMid:19491205 http://dx.doi.org/10.1093/jac/dkp196

[60] van Burik JA, Ratanatharathorn V, Stepan DE, Miller CB, Lipton JH, Vesole DH et al. Micafungin versus fluconazole for prophylaxis against invasive fungal infections during neutropenia in patients undergoing hematopoietic stem cell transplantation. Clin Infect Dis. 2004; 39(10): 1407-1416. PMid:15546073 http://dx.doi.org/10.1086/422312

[61] Mandhaniya S, Swaroop C, Thulkar S, Vishnubhatla S, Kabra SX, Xess I et al. Oral voriconazole versus intravenous low dose amphotericin B for primary antifungal prophylaxis in pediatric acute leukemia induction: a prospective, randomized, clinical study. J Pediatr Hematol Oncol. 2011; 33(8): e333-341. PMid:22042283 http://dx.doi.org/10.1097/MPH.0b013e3182331bc7

[62] Molina JR, Serrano J, Sánchez-García J, Rodriguez-Villa A, Gómez P, Tallón D et al. Voriconazole as primary antifungal prophylaxis in children undergoing allo-SCT. Bone Marrow Transplant. 2012; 47(4): 462-467. PMid:21572466 http://dx.doi.org/10.1038/bmt.2011.111 
[63] Wingard JR, Carter Sl, Walsh TJ, Kurtzberg J, Small TN, Baden LR et al. Randomized double-blind trial of fluconazole versus voriconazole for prevention of invasive fungal infection after allogeneic hematopoetic cell transplantation. Blood. 2010; 116(24): 5111-5118. PMid:20826719 http://dx.doi.org/10.1182/blood-2010-02-268151

[64] Cornely OA, Maertens J, Winston DJ, Perfect J, Ullman AJ, Walsh TJ et al. Posaconazole vs. fluconazole or itraconazole prophylaxis in patients with neutropenia. N Engl J Med. 2007; 356(4): 348-359. PMid:17251531 http://dx.doi.org/10.1056/NEJMoa061094

[65] Maertens JA, Madero L, Reilly AF, Lehrnbecher T, Groll AH, Jafri HS et al. A randomized, double-blind, multicenter study of caspofungin versus liposomal amphotericin B for empiric antifungal therapy in pediatric patients with persistent fever and neutropenia. Pediatr Infect Dis J. 2010; 29(5): 415-420. PMid:20431381 http://dx.doi.org/10.1097/INF.0b013e3181da2171

[66] Caselli D, Cesaro S, Ziino O, Ragusa P, Pontillo A, Pegoraro A et al. A prospective, randomized study of empirical antifungal therapy for the treatment of chemotherapy-induced febrile neutropenia in children. Br J Haematol. 2012; 158(2): $249-255$. PMid:22571507 http://dx.doi.org/10.1111/j.1365-2141.2012.09156.x

[67] Koo A, Sung L, Allen U, Naqvi A, Drynan-Arsenault J, Dekker A et al. Efficacy and safety of caspofungin for the empirec management of fever in neutropenic children. Pediatr Infect Dis J. 2007; 26(9): 854-856. PMid:17721388 http://dx.doi.org/10.1097/INF.0b013e318067b4d1

[68] Maertens J, Theunissen K, Verhoef G, Verschakelen J, Lagrou K, Verbeken E et al. Galactomannan and computed tomography-based preemptive antifungal therapy in neutropenic patients at high risk for invasive fungal infection: a prospective feasibility study. Clin Infec Dis. 2005; 41(9): 1242-1250. PMid:16206097 http://dx.doi.org/10.1086/496927

[69] Cordonnier C, Pautas C, Maury S, Vekhoff A, Farhat H, Suarez F et al. Empirical versus preemptive antifungal therapy for high-risk, febrile, neutropenic patients: a randomized, controlled trial. Clin Infect Dis. 2009; 48(8): 1042-1051. PMid:19281327 http://dx.doi.org/10.1086/597395

[70] Pagano L, Caira M, Nosari A, Cattaneo C, Fanci R, Bonini A et al. The use and efficacy of empirical versus pre-emptive therapy in the management of fungal infections: the HEMA e-Chart Project. Haematologica. 2011; 96(9): 1366-1370. PMid:21565903 http://dx.doi.org/10.3324/haematol.2011.042598

[71] Tan BH, Low JG, Chlebicka NL, Kurup A, Cheak FK, Lin RT et al. Galactomannan-guided preemptive vs. empirical antifungals in the persistently febrile neutropenic patient: a prospective randomized study. Int J Infect Dis. 2011; 15(5): e350-356. PMid:21397541 http://dx.doi.org/10.1016/j.ijid.2011.01.011

[72] Rojas R, Molina JR, Jarque I, Montes C, Serrano J, Sanz J et al. Outcome of Antifungal Combination Therapy for Invasive Mold Infections in Hematological Patients is Independent of the Chosen Combination. Mediterr J Hematol Infect Dis. 2012; 4(1): e201201.

[73] Garey KW, Rege M, Pai MP, Mingo DE, Suda KJ, Turpin RS et al. Time to initiation of fluconazole therapy impacts mortality in patients with candidemia: a multi-institutional study. Clin Infect Dis. 2006; 43(1): 25-31. PMid:16758414 http://dx.doi.org/10.1086/504810

[74] Pappas PG, Kauffman CA, Andes D, Benjamin DK Jr, Calandra TF, Edwards JE Jr et al. Clinical practice guidelines for the management of candidiasis: 2009 update by the infectious Disease Society of America. Clin Infect Dis. 2009; 48(5): 503-535. PMid:19191635 http://dx.doi.org/10.1086/596757

[75] Peman J, Canton E, Miñana JJ, Florez JA, Echeverria J, Ortega DN et al. Changes in the epidemiology of fungaemia and fluconazole susceptibility of blood isolates during the last 10 years in Spain: results form de FUNGEMYCA study. Rev Iberoam Micol. 2011; 28(2): 91-99. PMid:21376831

[76] Herbrecht R, Denning DW, Patterson TF, Bennet JE, Greene RE, Oestmann JW et al. Voriconazole versus amphotericin B for primary therapy of invasive aspergillosis. N Engl J Med. 2002; 347(6): 408-415. PMid:12167683 http://dx.doi.org/10.1056/NEJMoa020191

[77] Madero L, Sanchez de Toledo J, Castel V, Sevilla J, Gonzalez-Esteban J, Sanz-Rodriguez C. Compassionate use of caspofungin in children with proven or suspected invasive mycosis or persistent febrile neutropenia. J Chemother. 2009; 21(2): $229-231$. PMid:19423481

[78] Ryan M, Yeo S, Maguire A, Webb D, O`Marcaigh A, McDermott M et al. Rhinocerebral zygomycosis in childhood acute lymphoblastic leukaemia. Eur J Pediatr. 2001; 160(4): 235-238. PMid:11317646 http://dx.doi.org/10.1007/s004310000703

[79] Nucci M, Anaissie E. Fusarium infections in immunocompromised patients. Clin Microbiol Rev. 2007; 20(4): 695-704. PMid:17934079 http://dx.doi.org/10.1128/CMR.00014-07

[80] Troke P, Aguirrebengoa K, Arteaga C, Ellis D, Heath CH, Lutsar I et al. Treatment of Scedosporiosis with Voriconazole: Clinical Experience with 107 Patients. Antimicrob Agents Chemother. 2008; 52(5): 1743-1750.

PMid:18212110 http://dx.doi.org/10.1128/AAC.01388-07 
[81] Maertens J, Marchetti O, Herbrecht R, Cornely OA, Flückiger U, Frere P et al. European guidelines for antifungal management in leukemia and hematopoietic stem cell transplant recipients: summary of the ECIL 3-2009 update. Bone Marrow Transplant. 2011; 46(5): 709-718. PMid:20661235 http://dx.doi.org/10.1038/bmt.2010.175

[82] Cesaro S, Toffolutti T, Messina C, Calore E, Alaggio R, Cusinato R et al. Safety and efficacy of caspofungin and liposomal amphotericin B, followed by voriconazole in young patients affected by refractory invasive mycosis. Eur J Haematol. 2004; 73(1): 50-55. PMid:15182338 http://dx.doi.org/10.1111/j.1600-0609.2004.00254.x

[83] Yilmaz D, Balkan C, Ay Y, Akin M, Karapinar B, Kavakli K. A rescue therapy with a combination of caspofungin and liposomal amphotericin B or voriconazole in children with haematological malignancy and refractory invasive fungal infections. Mycoses. 2011; 54(3): 234-242. PMid:19906090 http://dx.doi.org/10.1111/j.1439-0507.2009.01808.x

[84] Caillot D, Thiebaut A, Herbrecht R, de Botton S, Pigneux A, Bernard F et al. Liposomal amphotericin B in combination with caspofungin for invasive aspergillosis in patients with hematologic malignancies: a randomized pilot study (Combistrat trial). Cancer. 2007; 110(12): 2740-2746. PMid:17941026 http://dx.doi.org/10.1002/cncr.23109

[85] Kontoyiannis DP, Ratanatharathorn V, Young J-A, Raymond J, Laverdiere M, Denning DW et al. Micafungin alone or in combination with other systemic antifungal therapies in hematopoietic stem cell transplant recipients with invasive aspergillosis. Transpl Infect Dis. 2009; 11(1): 89-93. PMid:18983417 http://dx.doi.org/10.1111/j.1399-3062.2008.00349.x

[86] Mihu CM, Kassis C, Ramos ER, Jiang Y, Hachem RY, Raad II. Does combination of lipid formulation of amphotericin B and echinocandins improve outcome of invasive aspergillosis en haematological malignancy patients? Cancer. 2010; 116(22): 5290-5296. PMid:20665889 http://dx.doi.org/10.1002/cncr.25312

[87] Cinicaltrials.gov. Anidulafungin Plus Voriconazole Versus Voriconazole For The Treatment Of Invasive Aspergillosis [Internet]. Available from: http.//clinicaltrtials.gov/ct2/show/NCT00531479.

[88] Cinicaltrials.gov. Voriconazole and Anidulafungin Combination for Invasive Aspergillosis in Pediatric Subjects [Internet]. Available from: http.//clinicaltrtials.gov/ct2/show/NCT01188759.

[89] Pharn HP, Rogoza K, Stotler D, Duffy D, Parker-Jones S, Ginzburg Y et al. Granulocyte Transfusion Therapy in Pediatric Patients After Hematopoietic Stem Cell Transplantation: A 5-Year Single Tertiary Care Center Experience. J Pediatr Hematol Oncol. 2012.

[90] Saint-Faust M, Boyer C, Gari-Toussaint M, Deville A, Poiree M, Weintraun M et al. Adjuvant corticosteroid therapy in 2 children with hepatoesplenic candidiasis-related IRIS. J Pediatr Hematol Oncol. 2009; 31(19): 794-796. PMid:19770685 http://dx.doi.org/10.1097/MPH.0b013e3181b795ec

[91] Bayram C, Fettah A, Yarali N, Kara A, Azik FM, Tavil B et al. Adjuvant corticosteroid therapy in hepatoesplenic candidiasis-related iris. Mediterr J Hematol Infect Dis. 2012; 4(1): e2012018. PMid:22550563 http://dx.doi.org/10.4084/mjhid.2012.018

[92] Reed C, Ibrahim A, Edwards JE Jr, Walot I, Epellberg B. Deferasirox, an iron-chelating agent, as salvage therapy for rhinocerebral mucormycosis. Antimicrob Agents Chemother. 2006; 50(11): 3968-3969. PMid:17000743 http://dx.doi.org/10.1128/AAC.01065-06

[93] Spellberg B, Ibrahim AS, Chin-Hong PV, Kontoyiannis DP, Morris MI, Perfect JR et al. The Deferasirox-AmBisome Therapy for Mucormycosis (DEFEAT Mucor) study: a randomized double-blinded, placebo-controlled trial. J Antimicrob Chemother. 2012; 67(3): 715-722. PMid:21937481 http://dx.doi.org/10.1093/jac/dkr375

[94] John BV, Chamillos G, Kontoyiannis DP. Hyperbaric oxygen as an adjunctive treatment for zygomycosis. Clin Microbiol Infect. 2005; 11(7): 515-517. PMid:15966968 http://dx.doi.org/10.1111/j.1469-0691.2005.01170.x

[95] Ostrosky-Zeichner L. Invasive Mycosis:. Diagnostic Challenges. Am J Med. 2012; 125(1 suppl): S14-24. PMid:22196205 http://dx.doi.org/10.1016/j.amjmed.2011.10.008

[96] Lain A, Elguezabal N, Moragues MD, Garcia-Ruiz JC, del Palacio A, Ponton J. Contribution of serum biomarkers to the diagnosis of invasive candidiasis. Expert Rev Mol Diagn. 2008; 8(3): 315-325. PMid:18598110 http://dx.doi.org/10.1586/14737159.8.3.315

[97] Van der Velden WJ, Blijlevens NM, Donnelly JP. Genetic variants and the risk for invasive mould disease in immunocompromised hematology patients. Curr Opin Infect Dis. 2011; 24(6): 554-563. PMid:21926619 http://dx.doi.org/10.1097/QCO.0b013e32834ab1f4

[98] Thompson GR 3rd, Wiederhold NP. Isavuconazole: a comprehensive review of spectrum of activity of a new triazole. Mycophatologia. 2010; 170(5): 291-313. PMid:20524153 http://dx.doi.org/10.1007/s11046-010-9324-3

[99] Warn PA, Sharp PA, Morissey G, Denning DW. Activity of aminocandin (IP960; HMR3270) compared with amphothericin B, itraconazole, caspofungin and micafungin in neutropenic murine models of disseminated infection caused by itraconazole-susceptible and -resistant strains of Aspergillus fumigatus. Int J Antimicrob Agents. 2010; 35(2): 146-151. PMid:20015618 http://dx.doi.org/10.1016/j.ijantimicag.2009.09.029

[100]Walker K. Interscience Conference on Antimicrobial Agents and Chemotherapy -50th Annual Meeting -Research on Promising Agents: Part 2. IDrugs. 2010; 13(11): 746-748. PMid:21046516 